Jurnal Indonesia Sosial Teknologi: p-ISSN: 2723 - 6609

e-ISSN : 2745-5254

Vol. 2, No. 1 Januari 2021

\title{
PERAN MEDIA SOSIAL DALAM KOMUNIKASI POLITIK
}

\section{Muzahid Akbar Hayat, Sjaiful Jayadiningrat, Gunawan Wibisono, dan Muhammad Iwu Iyansyah}

Uniska Syech Muhammad Arsyad Albanjari Banjarmasin

Email:m.akbarhayat@gmail.com, jayadiningratsjaiful@gmail.com, humasbatola@gmail.com dan iwuiyansyah89@gmail.com

\section{Abstract}

Every individual needs to communicate better, humans develop methods of communication and media. In this era, communication media has varied greatly thanks to the development of Information and Communication Technology (ICT). The development of ICT has prompted the birth of new media communications. New media communications such as Web 2.0 have an alternative medium of communication that is that social media has improved the efficiency and effectiveness of public communication. The current use of social media is not limited to everyday conversations, but has expanded into political communication. The interactive and flexible nature of social media has made it now widely used by both members of the public, politicians, and political parties in political communication. Social media has now become a major means of political campaigning and communication. However, politicians should be wise in using social media for political communication because the use of medium communication presents some advantages and disadvantages, especially for viewers. Combining traditional and social media for communication may be the best solution for maintaining engagement and communication with the audience.

Keyword : Social Media; Politicians; Political Communication; ICT

\section{Abstrak}

Setiap individu perlu berkomunikasi dengan lebih baik, manusia mengembangkan metode komunikasi dan media. Di era sekarang ini, media komunikasi telah sangat bervariasi berkat perkembangan Teknologi Informasi dan Komunikasi (TIK). Perkembangan TIK telah mendorong lahirnya komunikasi media baru. Komunikasi media baru seperti Web 2.0 memiliki alternatif media komunikasi yaitu media sosial telah meningkatkan efisiensi dan efektivitas komunikasi publik. Penggunaan media sosial saat ini tidak terbatas pada percakapan sehari-hari, tetapi telah diperluas ke komunikasi politik. Sifat interaktif dan fleksibel dari media sosial telah membuatnya sekarang banyak digunakan oleh baik anggota masyarakat, politisi, dan partai politik dalam komunikasi politik. Metode penelitian yang mengacu pada media sosial kini telah menjadi sarana utama untuk kampanye dan komunikasi politik. Namun, politisi harus bijak dalam menggunakan media sosial untuk komunikasi politik karena penggunaan komunikasi menengah ini menghadirkan beberapa kelebihan dan kekurangan, terutama bagi penonton. Hasil dari penelitian 
Muzahid Akbar Hayat, Sjaiful Jayadiningrat, Gunawan Wibisono, dan Muhammad Iwu Iyansyah

ini adalah Menggabangkan media tradisional dan sosial untuk komunikasi mungkin menjadi solusi terbaik untuk menjaga keterlibatan dan komunikasi dengan audiens.

Kata kunci: Media Sosial; Politisi; Komunikasi Politik; TIK

\section{Pendahuluan}

Dalam kehidupan sehari-hari setiap manusia tidak akan pernah lepas dari apa yang disebut komunikasi. Dari anak-anak hingga orang dewasa, dari orang-orang biasa di masyarakat hingga politisi di lembaga parlemen, semuanya membutuhkan komunikasi untuk mengekspresikan pemikiran dan kekhawatiran mereka tentang masalah apa pun yang mereka hadapi dalam hidup mereka. Komunikasi telah memungkinkan manusia untuk membahas berbagai masalah, membuat konstruksi sosial pada masalah tersebut dan membahayakan solusi untuk menghadapinya.

Komunikasi mengalami evolusi dari waktu ke waktu setelah evolusi peradaban manusia. Cara manusia berkomunikasi satu sama lain dan media yang mereka gunakan untuk komunikasi telah berevolusi dari waktu ke waktu. Sejak zaman dahulu hingga saat ini manusia telah mengembangkan metode dan media komunikasi. Metode komunikasi manusia terbatas pada komunikasi lisan, tatap muka, dan penulisan. Selain itu, media yang digunakan untuk berkomunikasi dengan audiens yang lebih luas juga terbatas pada media komunikasi tradisional seperti sinyal asap dan merpati pembawa yang digunakan untuk menyampaikan pesan tulisan yang ditulis (Yeger, 2015).

Sementara di zaman dahulu metode dan media untuk komunikasi sangat terbatas, di era sekarang ini mereka telah sangat bervariasi akibat kemajuan Teknologi Informasi dan Komunikasi (TIK). Perkembangan TIK telah menyebabkan lahirnya media dan metode baru untuk komunikasi. Akibatnya, saat ini manusia tidak lagi sangat bergantung pada komunikasi lisan dan tertulis, tetapi sekarang mereka juga berkomunikasi secara online menggunakan platform komunikasi media sosial. Media sosial kini telah banyak digunakan untuk komunikasi sehari-hari. Memang, telah digunakan untuk komunikasi politik oleh anggota masyarakat, politisi, dan partai politik (Stieglitz, Brockmann, \& Dang-Xuan, 2012).

Salah satu contoh keberhasilan dalam upaya menggunakan media sosial untuk komunikasi politik adalah dalam pemilihan presiden Amerika Serikat di tahun 2008. Dalam pemilihan itu mantan presiden Amerika Serikat yaitu Barack Obama mengintegrasikan media sosial dalam strategi kampanye politiknya dan dilakukan secara efektif, dengan maksud untuk mendukung kampanye pemilu offline-nya. Hasilnya, Obama memenangkan pemilihan dan menjabat pada 2009 (Bogost, 2017). Sejak itu, menyusul kesuksesan Obama dengan media sosial, dapat disaksikan peningkatan penggunaan media sosial untuk komunikasi politik seperti dalam kampanye pemilihan presiden dan legislatif di banyak negara di seluruh dunia. Jika dibandingkan dengan Indonesia, sekarang ini hampir semua aspek komunikasi dalam politik didukung oleh media sosial seperti partai politik di Indonesia. Dimana sudah banyak yang memiliki akun Facebook, Instagram, YouTube, dan Twitter di samping website resmi parpol. Sementara politisi masing-masing memiliki juga akun pribadi seperti jajaran para menteri, bahkan akun twitter presiden RI Joko Widodo (@jokowi) berstatus verified account, yang artinya sudah mendapatkan verifikasi dari pihak Instagram. Di sisi Twitter seperti program kerja, pendapat mengenai isu terkini, atau pembicaraan-pembicaraan yang sifatnya ringan, serta menanggapi mention dari 
masyarakat, adalah hal-hal yang umumnya tercantum dalam linimasa Twitter para tokoh politik tersebut.

Penelitian ini berpendapat bahwa media sosial memainkan peran pendukung dalam memediasi komunikasi politik antara anggota masyarakat, politisi dan partai politik. Bersama dengan media tradisional, media sosial menyediakan jalan alternatif untuk komunikasi politik, membuatnya lebih langsung dan interaktif. Dengan menggunakan media sosial, anggota masyarakat kini dapat lebih mudah menargetkan pejabat publik dan politisi untuk menyampaikan aspirasi, gagasan, dan kritik mereka atas isu dan agenda politik.

Meskipun penggunaan media sosial untuk tujuan komunikasi politik memberikan manfaat bagi anggota masyarakat. Namun, itu juga memberikan kerugian bagi mereka sebagai pengguna platform media ini. Oleh karena itu penelitian ini akan secara kritis membahas penggunaan media sosial untuk komunikasi politik. Pertama, akan menguraikan apa itu media sosial, perbedaannya dari media tradisional, dan perannya dalam komunikasi politik. Kedua, itu akan mengatasi potensi keuntungan dan kerugian bagi audiens ketika politisi menggunakan platform media ini untuk memotong media tradisional. Sehingga, pada penelitian ini akan memberikan diskusi, pembahasan, serta kesimpulan terkait media sosial untuk komunikasi politik.

\section{Metode Penelitian \\ Media Sosial}

Bagi sebagian besar anggota platform media sosial publik seperti Facebook, MySpace, Twitter, YouTube, dan Wikipedia, hanya untuk beberapa nama, bukanlah hal baru dalam menggunakan platform komunikasi media baru itu untuk berkomunikasi dan menjaga persahabatan dengan individu lain (Bogost, 2017). Komunikasi tersebut tidak terbatas pada lingkaran teman mereka sendiri tetapi juga untuk pengguna media sosial yang lebih luas di komunitas yang berbeda, waktu yang berbeda, dan agenda yang berbeda.

Meskipun media sosial telah mendapatkan popularitasnya di kalangan anggota publik dan sebagian besar juga dibahas dalam komunikasi dan sastra politik, namun tidak ada definisi tunggal mengenai media sosial (Effing, Van Hillegersberg, \& Huibers, 2011). Namun, sebagian besar akademisi media komunikasi setuju bahwa media sosial dapat didefinisikan sebagai sekelompok aplikasi berbasis Internet yang dibangun di atas fondasi ideologis dan teknologi Web 2.0, dan yang memungkinkan pembuatan dan pertukaran User Generated Content (Kaplan \& Haenlein, 2010). Berdasarkan definisi itu, dapat disimpulkan bahwa media sosial sama sekali bukan platform komunikasi baru, namun merupakan pengembangan web 2.0 dan dilengkapi dengan fitur yang memungkinkan penggunanya untuk secara mandiri dan mudah menghasilkan, menyebarluaskan, mendiskusikan, dan bertukar berbagai informasi dengan pengguna lain. Karakteristik unik ini telah membuat platform media sosial menjadi begitu populer di kalangan pengguna komunikasi media.

\section{Media Sosial dan Media Tradisional}

Meskipun media sosial dan media tradisional memiliki peran yang sama untuk memediasi informasi, namun sebenarnya merupakan dua platform media yang berbeda. Kedua platform media memiliki karakteristik berbeda yang membedakannya satu dengan yang lain (Gainous \& Wagner, 2013). Ada tiga perbedaan utama antara media 
Muzahid Akbar Hayat, Sjaiful Jayadiningrat, Gunawan Wibisono, dan Muhammad Iwu Iyansyah

sosial dan media tradisional yaitu pada model komunikasi, liputan media, dan produsen konten .

- Perbedaan pada Model Komunikasi, komunikasi media sosial adalah model komunikasi massa dua arah, sementara komunikasi media tradisional adalah model komunikasi massa satu arah (Gainous \& Wagner, 2013). Dalam proses komunikasi, media sosial memungkinkan komunikasi timbal balik antara pengguna dalam artian kedua pengguna aktif dalam menggunakan media. Ini berbeda dengan komunikasi media tradisional di mana komunikasi aktif tidak ada karena salah satu penggunanya aktif sementara yang lain tidak aktif (Gainous \& Wagner, 2013). Pada kampanye politik media tradisional, misalnya, pesan diproduksi oleh kandidat pemilu, disebarluaskan oleh media massa kepada konstituen dan pemilih mereka; dan hampir sepanjang waktu politisi telah menjadi pencipta informasi dan audiens telah menjadi audiens pasif. Sekali lagi, ini berbeda dengan kampanye media sosial di mana politisi dan calon pemilih dapat menghasilkan, menyebarluaskan, dan mendiskusikan pesan tersebut.

- Perbedaan pada Liputan Media, berkenaan dengan liputan media, media sosial dapat meliput audiens yang lebih luas daripada media tradisional. Komunikasi media sosial terjadi di lingkungan yang sangat terbuka, membuatnya memungkinkan informasi yang dianggap sebagai yang paling menarik atau menarik untuk didistribusikan ke audiens terluas (Gainous \& Wagner, 2013). Hal tersebut berbeda dengan komunikasi media tradisional di mana komunikasi dibatasi oleh jarak dan kondisi geografi. Surat kabar dan distribusi media cetak lainnya terbatas pada area yang dapat dijangkau oleh outlet penelitian baru dan sangat tergantung pada distribusi manual.

- Perbedaan pada Produsen Konten, meskipun ada pembagian yang jelas antara produsen konten dan pengguna di media tradisional; jurnalis profesional adalah produser informasi, sementara audiens adalah pengguna pasif informasi (Klinger \& Svensson, 2015) untuk platform media sosial, divisi semacam itu kabur karena tidak ada pembagian yang jelas antara kreator dan pengguna informasi. Tidak ada pembuat dan pengguna informasi yang pasti di media sosial, dan keduanya memainkan peran yang sama dengan pencipta dan pengguna informasi yang dikirimkan melalui media sosial.

\section{Hasil dan Pembahasan \\ Peran Media Sosial dalam Komunikasi Politik}

Kembali ke media sosial digunakan sebagai media komunikasi dimana di era demokrasi saat ini, penggunaan media sosial kini telah diperpanjang dari sekadar percakapan sehari-hari hingga komunikasi politik baik anggota masyarakat maupun politisi menggunakan media sosial untuk tujuan politik yang berbeda. Sementara anggota masyarakat menggunakan media sosial untuk membahas masalah politik, dan terlibat dengan organisasi masyarakat sipil dan pemimpin politik. Sebagian besar politisi menggunakannya sebagai media kampanye untuk mempertahankan citra publik mereka, dan sebagai media komunikasi untuk mempertahankan keterlibatan dengan wartawan dan audiens potensial mereka (Howard, Savage, Saviaga, Toxtli, \& MonroyHernández, 2016) . Oleh karena itu, tidak mengherankan jika saluran media sosial saat ini diisi dengan diskusi politik selain percakapan sehari-hari. 
Mempertimbangkan kekuatan platform media sosial untuk menyebarkan informasi penting serta besar ke audiens yang lebih luas, dan berkaca pada keberhasilan industri bisnis memasarkan produk mereka kepada pelanggan yang lebih luas dengan cara yang efisien dan efektif. Saat ini politisi cenderung merangkul komunikasi media sosial sebagai strategi mereka untuk berkomunikasi dengan audiens potensial mereka (Nulty, Theocharis, Popa, Parnet, \& Benoit, 2016), dengan media sosial sekarang telah menjadi platform utama untuk kampanye politik untuk mendapatkan dukungan dari calon pemilih, untuk mengumpulkan dana untuk partai politik, dan tujuan politik lainnya. Berikut ini adalah beberapa peran penting media sosial untuk komunikasi politik.

\section{a. Media Sosial Meningkatkan Efektivitas dan Efisiensi Kampanye Politik}

Kampanye politik menggunakan media sosial dapat lebih efektif dan efisien dalam menyasar calon pemilih. Contoh empiris telah menunjukkan bahwa media sosial dapat digunakan untuk kampanye politik dan mendukung strategi kampanye offline. Salah satu contoh keberhasilan penggunaan media sosial adalah dalam pemilihan presiden Amerika Serikat 2008. Selama kampanye pemilu, Barack Obama secara sistematis menggunakan platform media sosial sebagai sarana utama untuk menjalankan kampanyenya. Pada saat itu, ada lima belas platform media sosial yang digunakan oleh Obama bersama dengan situs webnya sendiri (Effing et al., 2011), dan ketika ia secara efektif menggunakan media sosial untuk kampanye politiknya, ia akhirnya terpilih sebagai presiden Amerika Serikat pada tahun 2008.

\section{b. Media Sosial Mendekatkan Politisi dengan Pemilihnya}

Berbeda dengan media tradisional, media sosial memungkinkan politisi dan audiens mereka untuk langsung berkomunikasi. Komunikasi ini dapat berlangsung di mana-mana pada waktu yang berbeda dan agenda yang berbeda. Di Meksiko, misalnya, seorang politisi Jaime Rodriguez Calderon yang dikenal sebagai 'El Bronco' telah berhasil menggunakan media sosial untuk menjaga komunikasi dan kedekatan dengan konstituennya. Dia menggunakan media sosial untuk kampanye politik di kampanye pemilihan gubernatorial dan terus menggunakannya jauh melampaui hari pemilihan untuk diskusi sehari-hari tentang kehidupan publik dengan publik negara bagian Nuevo Leon (Howard et al., 2016).

\section{c. Media Sosial Memediasi Komunikasi Politik dengan Audiens yang Lebih Luas}

Penggunaan media sosial dalam konteks politik internasional telah membantu politisi untuk berkomunikasi dengan audiens yang lebih luas dari berbagai kebangsaan dan bahasa. Dalam pemilihan parlemen Eropa 2014, misalnya, kandidat pemilu dan partai mereka menggunakan media sosial untuk berkomunikasi dengan audiens di 28 negara anggota Uni Eropa. Media sosial telah menyediakan sarana teknologi yang unik untuk menjembatani pemisahan linguistik, serta untuk memperluas jangkauan komunikasi politik oleh kandidat dan partai kepada para pemilih yang terletak di sistem politik multi-nasional Uni Eropa.(Nulty et al., 2016)

Dari penjelasan tersebut dapat disimpulkan bahwa media sosial telah menjadi media komunikasi alternatif selain media tradisional, karena dibangun berdasarkan konsep Web 2.0. Selain itu, media sosial memiliki karakteristik unik yang membedakannya dengan media tradisional. Media sosial juga memainkan peran penting 
Muzahid Akbar Hayat, Sjaiful Jayadiningrat, Gunawan Wibisono, dan Muhammad Iwu Iyansyah

dalam komunikasi politik dan telah berkontribusi pada peningkatan dalam cara komunikasi politik dilaksanakan.

\section{Kelebihan dan Kekurangan Penggunaan Media Sosial}

Setelah membahas tentang karakteristik media sosial, perbedaannya dari media tradisional, dan perannya dalam komunikasi politik, ada baiknya juga untuk membahas kelebihan dan kekurangan penggunaan media sosial bagi anggota masyarakat sebagai audiensi politik. Media sosial telah berkontribusi positif terhadap perkembangan komunikasi politik dengan menyediakan platform baru yang memfasilitasi komunikasi politik yang lebih langsung dan interaktif (Nulty et al., 2016) karena membantu untuk meningkatkan komunikasi antara anggota masyarakat dan politisi. Salah satunya ialah media sosial telah membantu politisi untuk mendapatkan keuntungan politik daripada sistem komunikasi yang ditingkatkan. Menggunakan media sosial politisi sekarang dapat melakukan kampanye politik dan komunikasi politik lainnya secara efisien dan efektif.

Namun, meskipun penggunaan media sosial untuk komunikasi politik memberikan manfaat bagi politisi, itu juga menghadirkan beberapa kelemahan yang harus menjadi perhatian para politisi. Salah satu kemungkinan kerugian dari penggunaan media sosial bagi politisi adalah bahwa operasi media sosial membutuhkan keterampilan dan sumber daya yang memadai. Karena tidak semua politisi melek internet dan keterampilan komunikasi yang cukup, dengan demikian bisa sangat sulit bagi mereka untuk mengimbangi aplikasi media sosial (Howard et al., 2016). Selain itu, mengoperasikan media sosial juga memakan waktu. Sifat platform media sosial yang memungkinkan komunikasi dua arah akan memaksa politisi untuk mengalokasikan banyak waktu untuk menanggapi komentar dan posting audiens yang melimpah yang dapat menimbulkan kesulitan bagi politisi untuk menanggapi semua konten audiens. Untuk menghadapi masalah ini politisi kemudian cenderung menunjuk seseorang untuk memberikan tanggapan kepada audiens mereka yang menciptakan beban lain bagi sumber daya manusia dan manajemen (Howard et al., 2016).

Kerugian lainnya adalah bahwa menggunakan media sosial sebagai media komunikasi politik di lingkup publik secara online yang akan membuat politisi memiliki kurang kontrol atas informasi yang tersedia tentang mereka di dunia maya (Kaplan \& Haenlein, 2010). hal tersebut akan membuat semakin sulit bagi politisi untuk mempertahankan citra positif mereka atas konstituen potensial karena pengguna media sosial mungkin dapat menghasilkan dan menyebarluaskan sebanyak mungkin informasi menyesatkan pada politisi ke saluran media sosial.

Pemilihan Gubernatorial DKI Jakarta 2017 di Indonesia dapat menjadi contoh empiris atas kerugian penggunaan media sosial untuk kampanye politik kandidat. Selama proses pemilu ini dapat disaksikan masifnya penggunaan media sosial secara negatif untuk kampanye hitam atas calon satu pemilu Basuki Cahaya Purnama yang dikenal sebagai Ahok. Media sosial telah menginspirasi pengguna untuk mempraktikkan ujaran kebencian yang menyuburkan sentimen sektarian dan rasis (Lim, 2017), sambil mengesampingkan politisi sebagai pengamat tak berdaya yang tidak dapat mengubah komentar negatif yang diposting secara publik. Hal ini relevan ketika Ahok dan timnya gagal memulihkan citra publiknya meskipun pesan kontra besar-besaran telah diposting ke publik melalui media sosial. 
Namun, terlepas dari kelebihan dan kekurangan dalam menggunakan media sosial untuk politisi, sejumlah literatur mennyatakan bahwa juga terdapat kemungkinan keuntungan dan kerugian bagi audiens ketika politisi menggunakan platform media ini untuk melewati media tradisional. Pertama, platform media sosial akan memungkinkan keterlibatan langsung antara anggota masyarakat dan politisi dalam kegiatan politik. Berbeda dari akses penggunaan media tradisional yang sulit didapatkan karena meningkatnya daya saing dengan audiens politik lainnya. Karakteristik media sosial yang menyediakan akses terbuka dan gratis kepada penggunanya (Klinger \& Svensson, 2015) memudahkan anggota masyarakat untuk berkomunikasi dan mentransfer pesan mereka langsung ke politisi. Oleh karena itu, penggunaan media sosial akan meningkatkan kemungkinan anggota masyarakat untuk terlibat langsung dengan politisi dan partai politik.

Kedua, penggunaan media sosial untuk komunikasi politik akan meningkatkan partisipasi politik anggota masyarakat(Lilleker, 2015). Tidak seperti komunikasi politik menggunakan media tradisional yang menghasilkan komunikasi satu arah, komunikasi media sosial memungkinkan komunikasi dua arah. Komunikasi timbal balik ini akan mendorong masyarakat untuk menjadi peserta yang lebih aktif. Penggunaan media sosial akan mendorong munculnya suara baru dalam debat politik (Scaramuzzino \& Scaramuzzino, 2017) sebagai individu menjadi peserta yang lebih aktif.

Ketiga, media sosial memberikan alternatif akses komunikasi dengan politisi. Jika puluhan tahun terakhir komunikasi politik sebagian besar dilakukan melalui saluran media tradisional, saat ini komunikasi ini juga bisa dilakukan melalui media sosial. Sebagai anggota publik dan aktor politik saat ini telah banyak menggunakan media sosial sebagai sarana untuk komunikasi politik (Nulty et al., 2016). Saat ini komunikasi antara kedua belah pihak tidak lagi bergantung pada mediasi media tradisional. Baik anggota masyarakat maupun politisi tidak perlu lagi bersaing untuk mendapatkan ruang di media tradisional untuk diskusi politik. Dengan adanya media sosial kedua belah pihak dapat menggunakannya untuk membuat domain sendiri untuk membahas isu politik.

Terakhir, penggunaan media sosial meningkatkan literasi politik anggota masyarakat. Penggunaan media sosial untuk komunikasi politik memungkinkan anggota masyarakat untuk mendapatkan lebih banyak informasi tentang politik dan meningkatkan kesempatan mereka untuk mempelajarinya. Oleh karena itu, ada baiknya bagi politisi dan partai politik, bersama dengan media tradisional, menggunakan media sosial untuk pendidikan politik baik untuk konstituen mereka dan audiens politik yang lebih luas (Speakman, 2015).

Terlepas dari keuntungan penggunaan media sosial di atas bagi audiens, penggunaan media sosial juga memiliki beberapa kelemahan. Pertama, penggunaan media sosial dalam komunikasi politik dapat membatasi partisipasi publik dalam kegiatan politik. Salah satu faktor yang berkontribusi pada pembatasan ini adalah sensor pemerintah terhadap media sosial. Hal ini disebabkan oleh peraturan sensor yang diterapkan oleh pemerintah. Penerapan sensor media oleh beberapa negara seperti di Zimbabwe, Indonesia, China dan Turki telah menimbulkan tantangan penggunaan media sosial untuk komunikasi politik terutama bagi anggota masyarakat. Di negaranegara seperti itu di mana penyensoran diterapkan dengan ketat ke semua platform media, melakukan komunikasi politik melalui media sosial akan sulit. Akan sulit bagi anggota masyarakat untuk sepenuhnya terlibat dalam komunikasi politik dengan politisi terutama yang dianggap sebagai oposisi terhadap pemerintah. Akan ada banyak risiko 
Muzahid Akbar Hayat, Sjaiful Jayadiningrat, Gunawan Wibisono, dan Muhammad Iwu Iyansyah

yang dihadapi oleh anggota masyarakat untuk menghasilkan, berkomunikasi, dan mendiskusikan isu-isu sensitif terutama yang bertujuan untuk mengkritik pemerintahan mereka. Di Cina dan Turki kedua pemerintah pusat mengerahkan kontrol berlebihan atas penggunaan media sosial publik (Miller et al., 2016, hal. Sebagai hasil dari kontrol ini, publik di Cina menggunakan media sosial untuk hiburan alih-alih komunikasi politik, sementara di Turki tenggara menggunakan media sosial untuk mengkritik pemerintah akan mengekspos pengguna terhadap sanksi pemerintah.

Faktor lain yang berkontribusi pada terbatasnya partisipasi publik dalam komunikasi politik yang disebabkan oleh penggunaan media sosial adalah perpecahan digital yang ada. Fakta bahwa pemisahan digital masih ada dalam komunitas di setiap negara juga berkontribusi pada batas partisipasi publik dalam kegiatan politik. Pemisahan digital itu sendiri dapat didefinisikan sebagai kondisi di mana beberapa proporsi masyarakat yang kurang mampu tidak mengakses Internet, sementara beberapa proporsi lain yang kaya, kelas menengah, dan muda yang tinggal di daerah perkotaan memiliki akses ke Internet (Norris, 2001). Pemisahan digital yang ada telah membuat penggunaan media sosial untuk komunikasi politik tidak efektif karena tidak semua anggota masyarakat dapat mengakses platform media. Oleh karena itu penggunaan media sosial akan mengecualikan mereka untuk berpartisipasi dalam kegiatan politik dan meningkatkan defisit demokrasi.

Kedua, penggunaan media sosial dalam komunikasi politik akan meningkatkan marginalisasi terhadap anggota masyarakat tertentu. Fakta bahwa tidak semua anggota masyarakat memiliki akses ke Internet akan membuat penggunaan media sosial meningkatkan marginalisasi dan polarisasi audiens politik, meninggalkan kelompok terpinggirkan akses terbatas ke partisipasi politik online. Kondisi ini akan mengurangi peluang mereka untuk berinteraksi dan berkomunikasi dengan para politisi untuk menyampaikan aspirasi, pemikiran, dan kritikus mereka.

Ketiga, penggunaan media sosial adalah sumber daya dan keterampilan yang menuntut (Scaramuzzino \& Scaramuzzino, 2017). Untuk beroperasi, pengguna media sosial membutuhkan perangkat seperti ponsel dan komputer dan harus ada infrastruktur Internet. Selain itu, yang paling penting adalah bahwa pengguna harus melek internet. Prakondisi tersebut telah membuat penggunaan media sosial tidaklah mudah. Meskipun pembagian digital di komunitas tertentu menurun yang ditandai dengan peningkatan pada perkembangan dan meratanya distribusi infrastruktur Internet, aplikasi media sosial yang beroperasi masih menimbulkan tantangan bagi anggota masyarakat karena masalah literasi.

Faktor lain yang mungkin membatasi penggunaan media sosial adalah bahwa fakta bahwa platform media ini tidak sepenuhnya media gratis. Untuk mengoperasikan aplikasi media sosial seperti Facebook, Twitter, Telegram, dan Blackberry Messenger, misalnya, pengguna platform media sosial tersebut harus memiliki koneksi internet; dan untuk memiliki koneksi seperti itu tidak selalu gratis.

Terakhir, penggunaan media sosial meningkatkan polarisasi di kalangan anggota masyarakat. Penggunaan media sosial untuk komunikasi politik mendorong pembentukan kelompok dalam masyarakat berdasarkan ideologi dan preferensi politik. Hal ini disebabkan oleh pengguna media sosial cenderung menjalin persahabatan dan komunikasi dengan pengguna yang memiliki preferensi dan ideologi politik yang sama.

Dari pembahasan tersebut ditemukan bahwa menggunakan media sosial sebagai platform komunikasi politik memiliki kelebihan dan kekurangan bagi publik. Oleh 
karena itu perlu dipertimbangkan bagaimana menghadapi kerugian dalam rangka meningkatkan manfaat menggunakan media sosial bagi anggota politik masyarakat. Politisi harus mempertimbangkan menggabungkan media tradisional dan sosial sebagai media untuk komunikasi. Kombinasi kedua media kemungkinan akan meningkatkan efisiensi dan efektivitas komunikasi politik.

\section{Kesimpulan}

Setiap individu perlu berkomunikasi. Komunikasi telah memungkinkan individu untuk terus berinteraksi satu sama lain untuk mengekspresikan kekhawatiran mereka dan memikirkan masalah dan kesulitan yang mereka hadapi dalam kehidupan seharihari mereka. untuk berkomunikasi dengan lebih baik, manusia mengembangkan metode komunikasi dan media. Akibatnya, metode komunikasi dan media selalu berubah serta mengikuti perkembangan peradaban manusia.

Di era sekarang ini, media komunikasi telah sangat bervariasi berkat perkembangan teknologi informasi dan komunikasi (TIK). Perkembangan TIK telah mendorong lahirnya komunikasi media baru. Komunikasi media baru seperti Web 2.0 memiliki alternatif media komunikasi. Perkembangan terbaru Web 2.0 yaitu media sosial telah meningkatkan efisiensi dan efektivitas komunikasi publik. Jika dalam beberapa dekade terakhir, peran mediasi dan penyebaran informasi hanya pada media tradisional seperti media cetak, TV, dan radio, namun sekarang media sosial telah dapat menggantikannya.

Penggunaan media sosial saat ini tidak terbatas pada percakapan sehari-hari, tetapi telah diperluas ke komunikasi politik. Sifat interaktif dan fleksibel dari media sosial telah membuatnya sekarang banyak digunakan oleh baik anggota masyarakat, politisi, dan partai politik dalam komunikasi politik. Media sosial kini telah menjadi sarana utama untuk kampanye dan komunikasi politik. Namun, politisi harus bijak dalam menggunakan media sosial untuk komunikasi politik karena penggunaan komunikasi menengah ini menghadirkan beberapa kelebihan dan kekurangan, terutama bagi penonton. Menggabungkan media tradisional dan sosial untuk komunikasi mungkin menjadi solusi terbaik untuk menjaga keterlibatan dan komunikasi dengan audiens. 
Muzahid Akbar Hayat, Sjaiful Jayadiningrat, Gunawan Wibisono, dan Muhammad Iwu Iyansyah

\section{Bibliography}

Bogost, Ian. (2017). Obama was too good at social media. Dostupno Na: Https://Www. Theatlantic.Com/Technology/Archive/2017/01/Did-America-Need-a-SocialMediapresident/512405/[20. Listopada 2017.].

Effing, Robin, Van Hillegersberg, Jos, \& Huibers, Theo. (2011). Social media and political participation: are Facebook, Twitter and YouTube democratizing our political systems? International Conference on Electronic Participation, 25-35. Springer.

Gainous, Jason, \& Wagner, Kevin M. (2013). Tweeting to power: The social media revolution in American politics. Oxford University Press.

Howard, Philip N., Savage, Saiph, Saviaga, Claudia Flores, Toxtli, Carlos, \& MonroyHernández, Andrés. (2016). Social media, civic engagement, and the slacktivism hypothesis: Lessons from Mexico’s “El Bronco.” Journal of International Affairs, 70(1), 55-73.

Kaplan, Andreas M., \& Haenlein, Michael. (2010). Users of the world, unite! The challenges and opportunities of Social Media. Business Horizons, 53(1), 59-68.

Klinger, Ulrike, \& Svensson, Jakob. (2015). The emergence of network media logic in political communication: A theoretical approach. New Media \& Society, 17(8), 1241-1257.

Lilleker, Darren G. (2015). Interactivity and Political Communication: hypermedia campaigning in the UK. Comunicação Pública, 10(18).

Lim, Merlyna. (2017). Freedom to hate: social media, algorithmic enclaves, and the rise of tribal nationalism in Indonesia. Critical Asian Studies, 49(3), 411-427.

Norris, Pippa. (2001). Digital divide: Civic engagement, information poverty, and the Internet worldwide. Cambridge university press.

Nulty, Paul, Theocharis, Yannis, Popa, Sebastian Adrian, Parnet, Olivier, \& Benoit, Kenneth. (2016). Social media and political communication in the 2014 elections to the European Parliament. Electoral Studies, 44, 429-444.

Scaramuzzino, Gabriella, \& Scaramuzzino, Roberto. (2017). The weapon of a new generation?-Swedish Civil Society Organizations' use of social media to 
influence politics. Journal of Information Technology \& Politics, 14(1), 46-61.

Speakman, Burton. (2015). Interactivity and political communication: New media tools and their impact on public political communication. Journal of Media Critiques, 1(1), 131-144.

Stieglitz, Stefan, Brockmann, Tobias, \& Dang-Xuan, Linh. (2012). Usage Of Social Media For Political Communication. PACIS, 22.

Yeger, Herman. (2015). The evolution of human communication. Journal of Cell Communication and Signaling, 9(3), 289-290. 